\title{
Analysis of the Main Girder of the Double-Beam Bridge Crane with Two Trolleys
}

\author{
Goran Pavlović ${ }^{*}$, Mile Savković2 , Goran Marković ${ }^{2}$, Nebojša Zdravković2 \\ ${ }^{1}$ Faculty of Electronic Engineering, University of Niš, Niš (Serbia) \\ ${ }^{2}$ Faculty of Mechanical and Civil Engineering in Kraljevo, University of Kragujevac, Kraljevo (Serbia)
}

In this research, the problem of calculating the necessary static quantities of the main girder with the box crosssection of the double-beam bridge crane with two trolleys were analyzed. The aim is to determine the critical position on the girder due to the action of all loads in the vertical plane, as a function of input parameters, and to obtain expressions for calculating deflections in the vertical and horizontal planes, as well as bending moments in these planes, ie maximum (total) stress in the girder. Verification of the results was carried out in the SAP2000 software package, with proved a quite good correlation between the results obtained, for the proposed method of the calculation model of the box-girder, in the mentioned software package. The goal of this research is primarily to show how the application of the SAP2000 software package in an easy, fast and simple way can perform the dimensioning and design of this type of carrying structures, taking into account important static conditions that must be satisfied. By applying the proposed modelling method and using a certain module in the mentioned software package, the designer easily achieves the preliminary geometric values of the girder in the initial design phase, where he can completely rely on the obtained results. Also, all geometric quantities necessary for further phases in the design and calculation are obtained. Guidelines are given on how to prepare a calculation model in this software package for these types of carrying structures, as well as recommendations related to the design of these types of carrying structures made of S355 material.

\section{Keywords: Bridge crane, Stresses, Deflections, SAP2000}

\section{INTRODUCTION}

The application of high capacity double-girder bridge cranes is very present, especially in production facilities and industrial plants. Depending on the working conditions, type of production and material handling in the production halls, double-girder bridge cranes with two trolleys are often present (Figure 1).

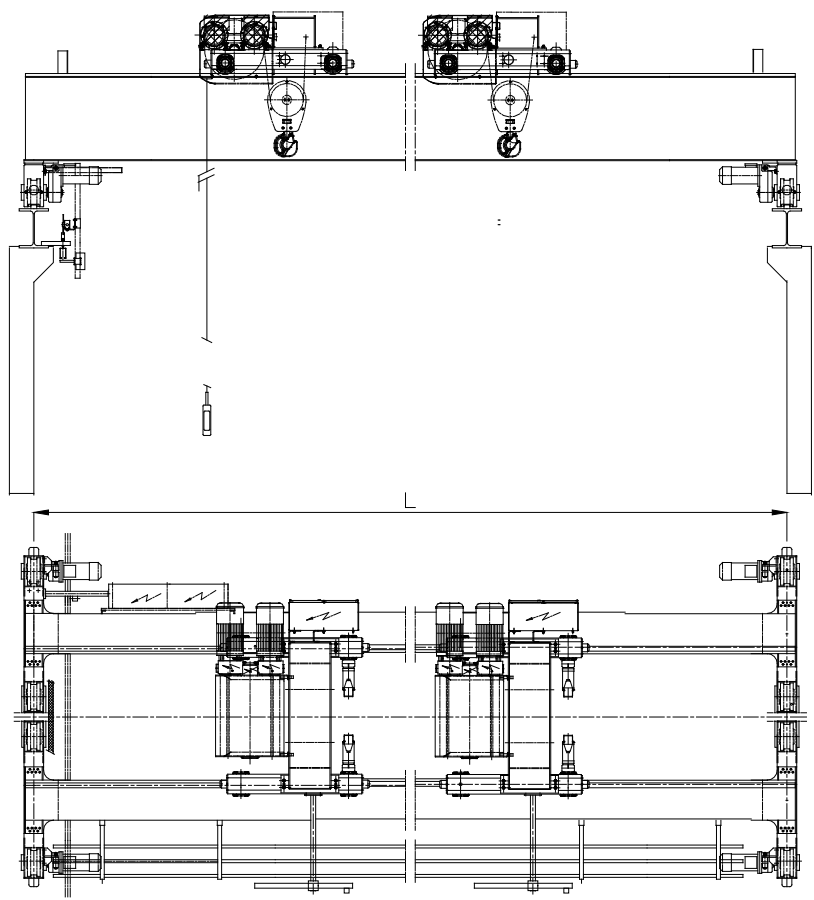

Figure 1: Double-girder bridge crane with two trolleys

Due to the great responsibility they have during operation, it is especially important to devote attention to the design of the main girders. This primarily includes the analysis of loads and the determination of the critical position on the main girder, as well as the calculation of all the necessary static quantities relevant for the dimensioning and design of the girder.

The analysis of the main crane girders implies, first of all, the determination of the values of deflection and stress states in the critical place of the girder. For these reasons, there is a large number of papers on this topic.

A detailed analysis of deflections on the example of one type of portal crane is presented in [1], where several characteristic positions of the load were observed. The importance of choosing the location of a load in the analysis, in the case of a double-girder bridge crane is shown in the paper [2], wherein the monitored characteristic positions of the trolley with a load at a reduced model of the crane. The experimental data obtained by measurement were compared with the analytical ones, whereby the differences of deflections and stresses were less than $9 \%$.

In [3], the optimization of the box-girder of the double-beam bridge crane was performed, whereby the critical position was observed. Deflections and stresses in the critical position according to DIN and FEM standards were analyzed in detail. Similar to the previous research, in the paper [4], the optimization of the box-girder of double-beam bridge crane with the criteria of lateral stability and local stability of the plates was performed. The paper [5] deals with the multicriteria optimization problem of the box-girder of the double-beam bridge crane. In addition to the analytical methods used for these types of structures, the finite element method is also used successfully [6-9]. The application of the ANSYS software package proved to be successful in the paper [6], where 
the bridge crane's girder with two positions of the trolley with the load was analyzed, showing a high agreement between these results and the analytical ones obtained according to the Indian standard. The mentioned software package was also used in the paper [7], where the analysis of the position of the trolley with loads on the girder and determination of the critical place on the girder where the maximum bending moment occurs was performed, on the example of the main girder of the single-beam bridge crane with 8-wheel trolley. In addition to determining the stress states, a modal analysis was performed, too.

In addition to the ANSYS software package, ABAQUS can be efficiently applied, as shown in [8], wherein the analysis of the structure of a double-girder bridge crane was performed. Two types of loads were considered, in this case. A good match between the analytical and numerical results was achieved on this occasion as well.

Optimization and analysis of girders with two trolleys are presented in papers [9] and [10]. In [9], the analysis and optimization of main the girder of a singlebeam bridge crane with complex cross-section were carried out, whereby two trolleys are symmetrically arranged on it. The results were verified by the FEM standard. The analysis of girders of the bridge crane with two trolleys for different capacities is presented in [10], where the main goal is a detailed analysis of the deflection of the girders. In addition to deflection, fatigue was also taken into account. The analysis of these types of structures can be performed with different types of model formation, as well as finite element types, which is shown in the paper [11], where guidelines for model formation for finite element analysis of these types of structures are given.

The above papers indicate the importance of a detailed analysis of the supports of these types of structures, especially the position of the critical place, as well as a detailed analysis of deflections and stress states.

This research aims to analyze loads of the bridge crane's girder with two trolleys, where the goal is to define the exact expressions for maximum deflections and stress states in the vertical and horizontal planes. Also, the application of the SAP2000 software package will be presented to define the calculation model of the girder that allows a simple and fast check of the girder, primarily in determining the maximum deflections.

\section{ANALYSE AND CALCULATION OF THE MAIN GIRDER}

The analysis of the main girder will be performed based on strength and stiffness in the critical place of the girder.

This analysis will be considered one double-girder bridge crane with two trolleys that is in exploitation.

A double-girder bridge crane, with a carrying capacity of $2 \times 25 \mathrm{t}$ and a span of $22.5 \mathrm{~m}$, will be used as an example. The dimensions of the main girder are shown in the following figure (Figure 2):

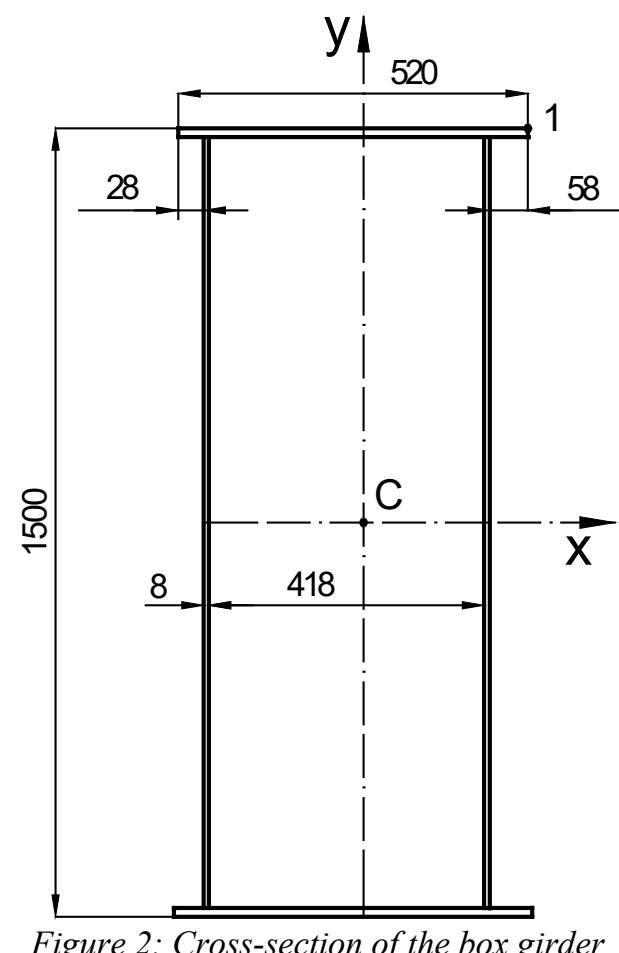

Figure 2 presents the cross-section of the main girder of the double-beam bridge crane with necessary dimensions, for the observed example.

\subsection{Static load model}

For analysis and calculation of the main girder of the double-beam bridge crane, the model of a simple beam on which the wheels of both trolleys act is observed, as well as the specific weight of the girder. This refers to the analysis in the vertical plane (Figure 3). Also, the effect of all loads that occurs in the horizontal plane is observed. First, the vertical plane will be observed, to determine the critical position relevant for the calculation.

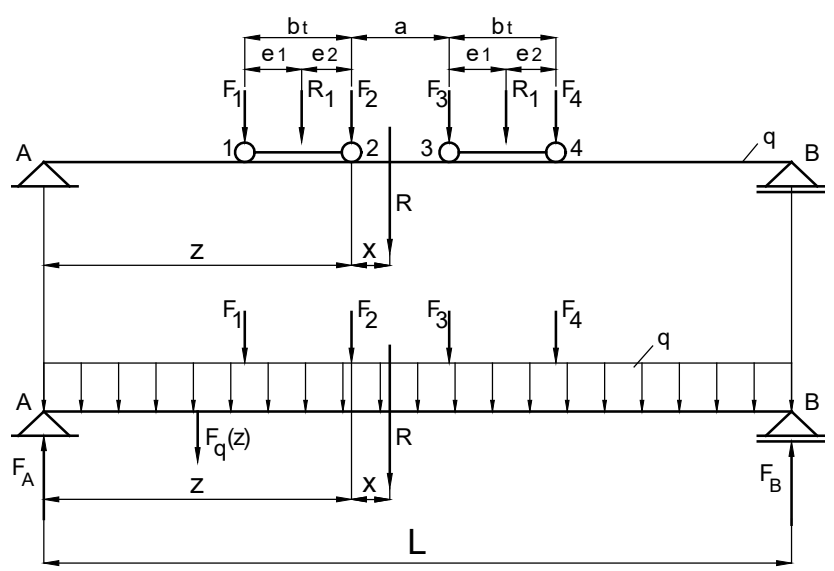

Figure 3: The static model of the girder with two trolleys in the vertical plane

The existing solution of a double-girder bridge crane, with a carrying capacity of $2 \times 25 \mathrm{t}$ and a span of $22.5 \mathrm{~m}$, will be used as an example for calculation. The classification class of the crane is 2, according to [12].

Figure 3 shows the static model of the girder with two trolleys in the vertical plane with all static quantities. 


\subsection{Determination of the critical position}

For determination of the critical position $z_{o}$, the position of point 2 of the first trolley, $z$ (current position) is observed, since the resulting force $\mathrm{R}$ is located between the two trolleys (Figure 3). The current position $z$ and the static equilibrium condition in the vertical plane are observed, and the expression (1) for the resulting force in the support A is obtained, depending on the current position $z$ :

$$
F_{A}(z) \cdot L=R \cdot c(z)+F_{q} \cdot \frac{L}{2}
$$

where:

$$
\begin{gathered}
R_{1}=\frac{\psi \cdot Q+m_{t}}{2} \cdot g \\
R_{1}=F_{1}+F_{2}=F_{3}+F_{4} \\
R=2 \cdot R_{1}=\left(\psi \cdot Q+m_{t}\right) \cdot g=F_{1}+F_{2}+F_{3}+F_{4} \\
F_{1}=F_{3}=\frac{R \cdot e_{2}}{2 \cdot b_{t}} \\
F_{2}=F_{4}=\frac{R \cdot e_{1}}{2 \cdot b_{t}} \\
b_{t}=e_{1}+e_{2} \\
F_{q}=q \cdot L \\
q=1.3 \cdot \rho \cdot g \cdot A \\
c(z)=L-(z+x) \\
x=\frac{e_{1}-e_{2}+a}{2}
\end{gathered}
$$

From the preceding expression is obtained:

$$
F_{A}(z)=\frac{R \cdot c(z)}{L}+\frac{q \cdot L}{2}
$$

where:

$F_{A}$ - the reaction force at support $A$ (Figure 3),

$R_{1}$ - the resultant force of the trolley (Figure 3),

$R$ - the resultant force of both trolleys (Figure 3),

$F_{1}, F_{2}, F_{3}, F_{4}$ - forces of pressure on the girder, from wheel 1, wheel 2, wheel 3. and wheel 4, respectively (Figure 3),

$$
M_{V, \text { max }}=M_{V, k}\left(z=z_{o}\right)=\gamma \cdot F_{A}\left(z=z_{o}\right) \cdot z_{o}-\gamma \cdot\left(F_{1} \cdot b_{t}+\frac{q \cdot z_{o}^{2}}{2}\right)
$$

where:

$$
\begin{aligned}
& \qquad \begin{array}{l}
F_{A}\left(z=z_{o}\right)=\frac{R}{L} \cdot\left(L-z_{o}-x\right)+\frac{q \cdot L}{2} \\
M_{H, \max }=\gamma \cdot F_{A H}
\end{array} \\
& \text { where: } \\
& \qquad \begin{aligned}
F_{A H}\left(z=z_{o}\right)=\frac{R_{H}}{L} \cdot\left(L-z_{o}-x\right)+k_{a} \cdot \frac{q \cdot L}{2} \\
R_{H}=k_{a} \cdot\left(Q+m_{t}\right) \cdot g \\
F_{1 H}=F_{3 H}=\frac{R_{H} \cdot e_{2}}{2 \cdot b_{t}} \\
F_{2 H}=F_{4 H}=\frac{R_{H} \cdot e_{1}}{2 \cdot b_{t}}
\end{aligned}
\end{aligned}
$$

$F_{1 H}, F_{2 H}, F_{3 H}, F_{4 H}$ - forces in the horizontal plane, from wheel 1 , wheel 2 , wheel 3 . and wheel 4 , respectively, $\gamma, \psi$ - coefficients, according to [12],

$q$ - the specific weight of the girder (increased by $30 \%$ due to the weight of the platform, longitudinal stiffeners, diaphragms, and welds),

$F_{q}$ - the force of the specific weight of the girder,

$m_{t}$ - the weight of the trolley,

$b_{t}$ - the distance between wheels of the trolley (Figure 3),

$e_{1}$ - the position of the resultant force of load in relation to the wheel 1 (Figure 3),

$e_{2}$ - the position of the resultant force of load in relation to the wheel 2 (Figure 3),

$a$ - the minimum distance between trolleys (Figure 3),

$x$ - the centre of gravity of the resultant force $R$ for both trolleys (Figure 3).

The bending moment in the vertical plane, in the critical place $z$ is determined based on the static equilibrium condition:

$$
M_{V, k}(z)=\gamma \cdot\left[F_{A}(z) \cdot z-F_{1} \cdot b-F_{q}(z) \cdot \frac{z}{2}\right]
$$

where:

$$
F_{q}(z)=q \cdot z
$$

The maximum bending moment is determined based on the known following condition:

$$
\frac{d}{d z}\left(M_{V, k}(z)\right)=0
$$

Finally:

$$
\frac{R}{L} \cdot(L-2 \cdot z-x)+\frac{q}{2} \cdot(L-2 \cdot z)=0
$$
obtained:

Based on (16), the value of the critical position is

$$
z_{o}=\frac{2 \cdot R \cdot(L-x)+q \cdot L^{2}}{2 \cdot(2 \cdot R+q \cdot L)}
$$

The maximum bending moment in the vertical plane is determined based on the following relation: $\rho$ - the density of the material of girder's material,

The maximum bending moment in the horizontal plane is also calculated for the determined critical position, the following relation:

$k_{a}$ - the dynamic coefficient of crane load in the horizontal plane, according to [12].

\subsection{Deflections of the main girder}

The total deflection in the vertical plane is calculated as the superposition of the deflections resulting from the action of the wheels of both trolleys and the specific weight of the girder.

$$
f_{V}=f_{V 1}+f_{V 2}+f_{V 3}+f_{V 4}+f_{V q} \leq f_{V, d}
$$

where:

$$
f_{V, d}=K_{V, f} \cdot L
$$




$$
\begin{aligned}
& f_{V 1}=\frac{\gamma \cdot F_{1} \cdot L^{3}}{6 \cdot E \cdot I_{x}}\left(\frac{b_{1} \cdot z_{o}}{L^{2}}\right)\left[1-\left(\frac{b_{1}}{L}\right)^{2}-\left(\frac{z_{o}}{L}\right)^{2}\right]+\frac{\gamma \cdot F_{1} \cdot L^{3}}{6 \cdot E \cdot I_{x}}\left(\frac{z_{o}-a_{1}}{L}\right)^{3} \\
& a_{1}=z_{o}-b_{t}, b_{1}=L-a_{1} \\
& f_{V 2}=\frac{\gamma \cdot F_{2} \cdot L^{3}}{3 \cdot E \cdot I_{x}} \cdot\left(\frac{z_{o}}{L}\right)^{2} \cdot\left(\frac{L-z_{o}}{L}\right)^{2} \\
& f_{V q}=\frac{\gamma \cdot q \cdot L^{4}}{24 \cdot E \cdot I_{x}} \cdot\left[\left(\frac{z_{o}}{L}\right)-2 \cdot\left(\frac{z_{o}}{L}\right)^{3}+\left(\frac{z_{o}}{L}\right)^{4}\right]
\end{aligned}
$$$$
f_{V 3}=\frac{\gamma \cdot F_{3} \cdot L^{3}}{6 \cdot E \cdot I_{x}}\left(\frac{b_{3} \cdot z_{o}}{L^{2}}\right)\left[1-\left(\frac{b_{3}}{L}\right)^{2}-\left(\frac{z_{o}}{L}\right)^{2}\right]
$$$$
a_{3}=z_{o}+a, b_{3}=L-a_{3}
$$$$
f_{V 4}=\frac{\gamma \cdot F_{4} \cdot L^{3}}{6 \cdot E \cdot I_{x}}\left(\frac{b_{4} \cdot z_{o}}{L^{2}}\right)\left[1-\left(\frac{b_{4}}{L}\right)^{2}-\left(\frac{z_{o}}{L}\right)^{2}\right]
$$$$
a_{4}=z_{o}+a+b_{t}, b_{4}=L-a_{4}
$$

$$
f_{H 1}=\frac{\gamma F_{1 H} \cdot L^{3}}{6 \cdot E \cdot I_{y}}\left(\frac{b_{1} \cdot z_{o}}{L^{2}}\right)\left[1-\left(\frac{b_{1}}{L}\right)^{2}-\left(\frac{z_{o}}{L}\right)^{2}\right]+\frac{\gamma F_{1 H} \cdot L^{3}}{6 \cdot E \cdot I_{y}}\left(\frac{z_{o}-a_{1}}{L}\right)^{3}
$$$$
f_{H 2}=\frac{\gamma \cdot F_{2 H} \cdot L^{3}}{3 \cdot E \cdot I_{y}} \cdot\left(\frac{z_{o}}{L}\right)^{2} \cdot\left(\frac{L-z_{o}}{L}\right)^{2}
$$$$
f_{H 3}=\frac{\gamma F_{3 H} \cdot L^{3}}{6 \cdot E \cdot I_{y}}\left(\frac{b_{3} \cdot z_{o}}{L^{2}}\right)\left[1-\left(\frac{b_{3}}{L}\right)^{2}-\left(\frac{z_{o}}{L}\right)^{2}\right]
$$$$
f_{H 4}=\frac{\gamma F_{4 H} \cdot L^{3}}{6 \cdot E \cdot I_{y}}\left(\frac{b_{4} \cdot z_{o}}{L^{2}}\right)\left[1-\left(\frac{b_{4}}{L}\right)^{2}-\left(\frac{z_{o}}{L}\right)^{2}\right]
$$$$
f_{H q}=\frac{k_{a} \cdot \gamma \cdot q \cdot L^{4}}{24 \cdot E \cdot I_{y}} \cdot\left[\left(\frac{z_{o}}{L}\right)-2\left(\frac{z_{o}}{L}\right)^{3}+\left(\frac{z_{o}}{L}\right)^{4}\right]
$$

$K_{H, f}$ - the coefficient that depends on the purpose of the crane and control condition of the crane in the horizontal plane, according to [12],

$I_{y}$ - the moment of inertia about the $y$-axis.

\subsection{Stresses of the main girder}

Stresses in the critical position of the main girder are observed.

The equivalent (total) stress in the critical place is:

$$
\sigma_{\max }=\sigma_{V}+\sigma_{H} \leq \sigma_{d}
$$

The permissible stress is:

$$
\sigma_{d}=\frac{R_{e}}{v_{1}}
$$

The maximum bending stress in the vertical plane is:

$$
\sigma_{V}=\frac{M_{V, \max }}{I_{x}} \cdot y_{\max }
$$
plane is:

The maximum bending stress in the horizontal

$$
\sigma_{H}=\frac{M_{H, \max }}{I_{y}} \cdot x_{\max }
$$

where:

$x_{\max }, y_{\max }-$ coordinates of the point where the stress check is performed (Figure 2),

$R_{e}$ - the minimum yield stress of the girder's material, according to [13],
$K_{V, f}$ - the coefficient that depends on the purpose of the crane and control condition of the crane, in the vertical plane, according to [12],

$E$ - the elastic modulus of the girder's material, $I_{x}$ - the moment of inertia about the $x$-axis.

Analogous to the previous one, the total deflection in the horizontal plane is calculated as follows:

$$
f_{H}=f_{H 1}+f_{H 2}+f_{H 3}+f_{H 4}+f_{H q} \leq f_{H, d}
$$

where:

$$
f_{H, d}=K_{H, f} \cdot L
$$

$v_{1}=1.5$ - the factored load coefficient for load case 1, according to [13].

\subsection{Analytical results}

Based on the expressions shown in Chapter 2.4, as well as on the input data for the example of the doublegirder bridge crane which is in operation (based on the project documentation), it is possible to calculate the values of deflection and maximum stress in the critical position.

The input data (characteristics of the crane) necessary for the calculation of the girder are as follows:

- the carrying capacity of the crane:

$$
Q=2 \times 25 \mathrm{t} \text {, }
$$

- the span of the crane:

$$
L=22.5 \mathrm{~m} \text {, }
$$

- the weight of the trolley:

$$
m_{t}=2 \times 2.57 \mathrm{t} \text {, }
$$

- the position of the resultant force of load in relation to the wheel 1:

$$
e_{1}=68.2 \mathrm{~cm},
$$

- the position of the resultant force of load in relation to the wheel 2:

$$
e_{2}=66.8 \mathrm{~cm} \text {, }
$$

- the minimum space between trolleys:

$$
a=45.2 \mathrm{~cm} \text {, }
$$

- the dynamic coefficient of crane load in the horizontal plane:

$$
k_{a}=0.05,
$$

- the material of the girder plates:

$$
\text { S355, }
$$

- the minimum yield stress of the girder's material:

$$
R_{e}=35.5 \mathrm{kN} / \mathrm{cm}^{2} \text {. }
$$

Geometrical characteristics of the main girder

(Figure 2):

- the cross-sectional area:

$$
A=360.96 \mathrm{~cm}^{2} \text {, }
$$

- the moment of inertia about the $x$-axis:

$$
I_{x}=1119571.7 \mathrm{~cm}^{4} \text {, }
$$

- the moment of inertia about the $y$-axis:

$$
I_{y}=135461.34 \mathrm{~cm}^{4} \text {, }
$$

- the distance from the $x$-axis to point 1 (Figure 2): 


$$
y_{\max }=75 \mathrm{~cm},
$$

- the distance from the $y$-axis to point 1 (Figure 2):

$$
x_{\max }=26.98 \mathrm{~cm} \text {. }
$$

The other input data were taken according to [12].

Finally, by applying the presented relations, the following results are obtained:

- the value of the critical position: $z_{o}=1114.711 \mathrm{~cm}$,

- the total deflection in the vertical plane:

$$
f_{V}=3.747 \mathrm{~cm}
$$

- the permissible deflection in the vertical plane: $f_{V, d}=4.50 \mathrm{~cm}$,

- the total deflection in the horizontal plane: $f_{H}=1.3896 \mathrm{~cm}$,

- the permissible deflection in the horizontal plane: $f_{H, d}=3.75 \mathrm{~cm}$,

- the maximum bending moment in the vertical plane: $M_{V, \max }=190963.32 \mathrm{kNcm}$,

- the maximum bending stress in the vertical plane: $\sigma_{V}=12.79 \mathrm{kN} / \mathrm{cm}^{2}$

- the maximum bending moment in the horizontal plane: $M_{H, \max }=8548.68 \mathrm{kNcm}$,

- the maximum bending stress in the horizontal plane: $\sigma_{H}=1.70 \mathrm{kN} / \mathrm{cm}^{2}$

- the total stress:

$$
\sigma_{\max }=14.49 \mathrm{kN} / \mathrm{cm}^{2},
$$

- the permissible stress:

$\sigma_{d}=23.67 \mathrm{kN} / \mathrm{cm}^{2}$.

As can be seen, all results are within acceptable limits. Research [14] shows that double-girder bridge cranes with a span of over $20 \mathrm{~m}$ with material S355 have a dominant stiffness condition or dynamic stiffness condition so that strength and global stability conditions are satisfied if the stiffness conditions are satisfied. In this case, it means that the strength condition is satisfied if the stiffness conditions are satisfied, which can be seen based on the obtained results. It is noticed that the stiffness condition in the vertical plane is the most critical, while the value of the total stress is far below the permissible value.

If the specific weight of the girder $q$ is neglected in (17), using the equation (11), the following value of the expression for the critical position is obtained:

$$
z_{o}=\frac{2 \cdot L-e_{1}+e_{2}-a}{4}
$$

Based on the expression (46), the value of the critical position is:

$$
z_{o}=1113.350 \mathrm{~cm} \text {, }
$$

where the values of deflections for these conditions remain the same, while the values of bending moments are almost identical:

- the maximum bending moment in the vertical plane:

$$
M_{V, \max }=190963.02 \mathrm{kNcm} \text {, }
$$

- the maximum bending moment in the horizontal plane:

$$
M_{H, \max }=8548.66 \mathrm{kNcm} \text {. }
$$

In this case, the specific weight is not of great importance for determining the critical position, primarily because the load pressures of both trolley's wheels are more dominant than the specific weight.

However, if the influence of specific weight is neglected, then the following is obtained:

- the total deflection in the vertical plane:

$$
f_{V}=3.208 \mathrm{~cm}
$$

- the total deflection in the horizontal plane:

$$
f_{H}=1.1671 \mathrm{~cm} \text {, }
$$

- the maximum bending moment in the vertical plane:

$$
M_{V, \max }=166954.86 \mathrm{kNcm} \text {, }
$$

- the maximum bending stress in the vertical plane:

$$
\sigma_{V}=11.18 \mathrm{kN} / \mathrm{cm}^{2} \text {, }
$$

- the maximum bending moment in the horizontal plane:

$$
M_{H, \max }=7348.25 \mathrm{kNcm} \text {, }
$$

- the maximum bending stress in the horizontal plane:

$$
\sigma_{H}=1.46 \mathrm{kN} / \mathrm{cm}^{2}
$$

- the total stress:

$$
\sigma_{\max }=12.64 \mathrm{kN} / \mathrm{cm}^{2} \text {. }
$$

A significant influence on the deflection in the vertical plane, bending moment and stress in the vertical plane is observed.

\subsection{Results from SAP2000}

In the SAP2000 software package, the main girder is simply generated using a line model, while the box cross-section is defined using the Section Designer module (Figure 4).

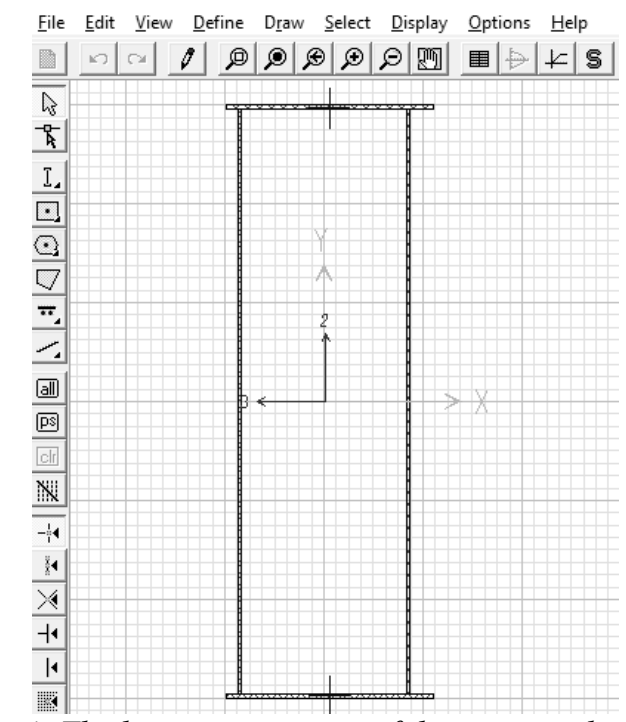

Figure 4: The box cross-section of the main girder defined in the Section Designer module (SAP2000)

Based on this module, the necessary geometrical characteristics of the cross-section are automatically obtained (Figure 5).

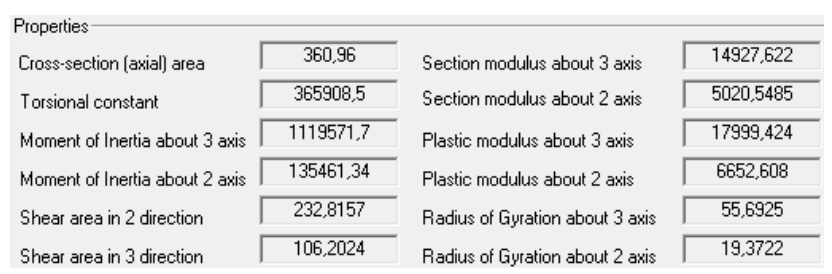

Figure 5: Geometric characteristics determined in SAP2000

Figure 6 presents the 3D model for the FEM analysis in SAP2000 software, which consists of the main girder modelled by beam finite elements, and Figure 7 shows the static load model of the girder. 


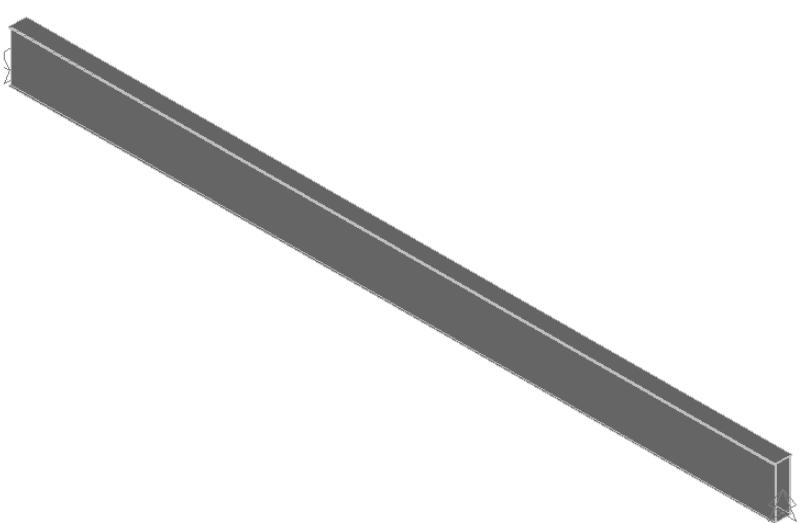

Figure 6: The 3D model of the girder in SAP2000

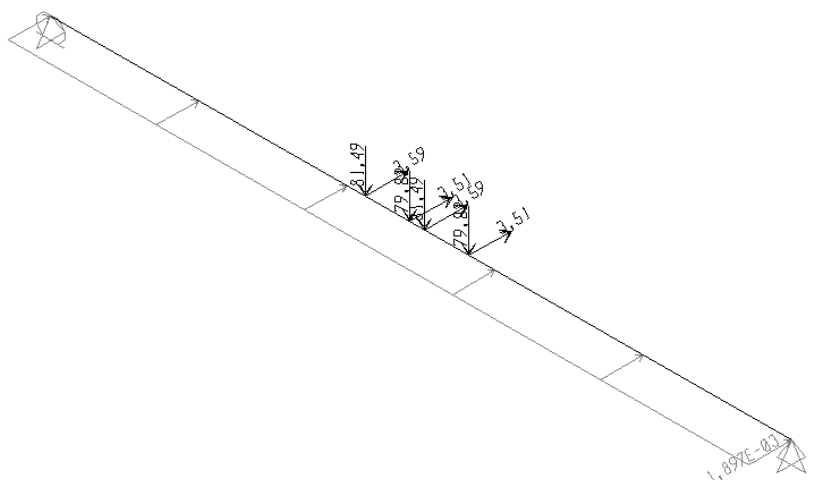

Figure 7: The static load model of the girder in SAP2000

With this type of model, analysis and calculation, all calculation results are obtained in a simple and fast way.

Figures 8 and Figure 9 represent the static load model of the girder in the vertical plane as well as static diagrams, respectively.

The weight of the girder increased by the certain factor value was taken into analysis automatically, when defining the load combination in this software package (Figure 8).

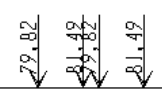

Figure 8: The static load model of the girder in SAP2000 (vertical plane)

Figure 9 presents diagrams of the distribution of bending moment as well as deflection in the vertical plane.

As can be seen from static diagrams (Figure 9), values of deflection and bending moment in the vertical plane are:

- the total deflection in the vertical plane:

$$
f_{V}=3.757 \mathrm{~cm}<f_{V, d}=4.50 \mathrm{~cm},
$$

- the maximum bending moment in the vertical plane:

$M_{V, \max }=191428.30 \mathrm{kNcm}$,

while the calculation gives:

- the maximum bending stress in the vertical plane:

$\sigma_{V}=12.82 \mathrm{kN} / \mathrm{cm}^{2}$.

It is similar to the horizontal plane.

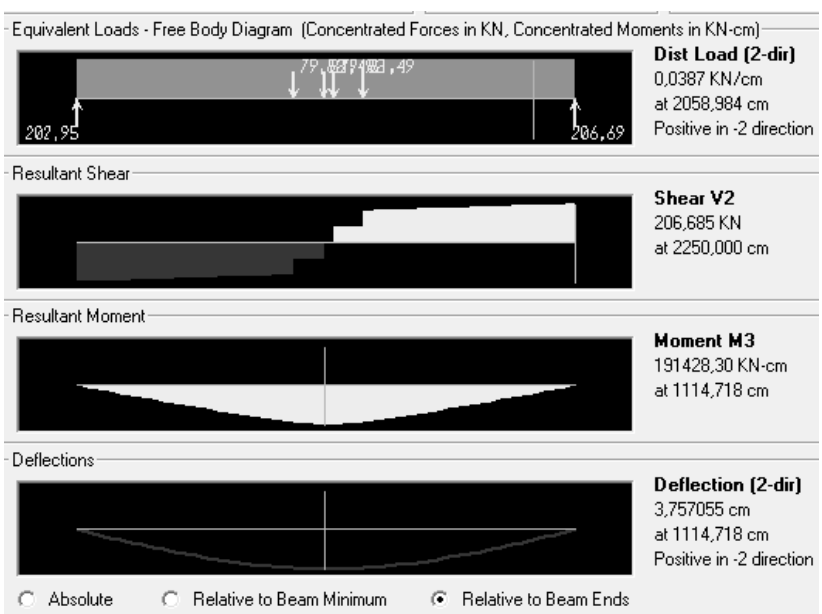

Figure 9: Static diagrams in the vertical plane

Figure 10 and Figure 11 represent the static load model of the girder in the horizontal plane as well as static diagrams, respectively.

The static load model is shown in the following figure (Figure 10):

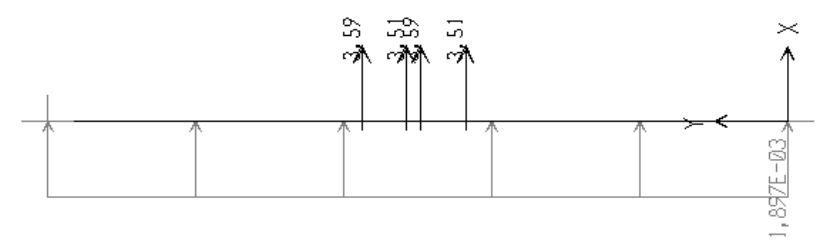

Figure 10: The static load model of the girder in SAP2000 (horizontal plane)

The following figure presents diagrams of the distribution of bending moment as well as deflection in the horizontal plane (Figure 11):

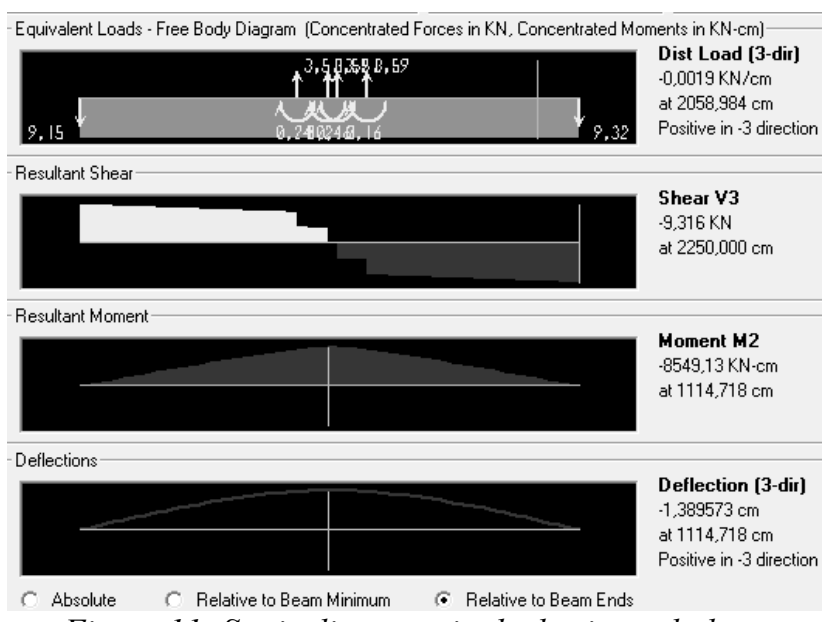

Figure 11: Static diagrams in the horizontal plane

As can be seen from static diagrams (Figure 11), values of deflection and bending moment in the horizontal plane are:

- the total deflection in the horizontal plane:

$$
f_{H}=1.3896 \mathrm{~cm}<f_{H, d}=3.75 \mathrm{~cm} \text {, }
$$

- the maximum bending moment in the horizontal plane:

$M_{H, \max }=8549.13 \mathrm{kNcm}$,

while the calculation gives:

- the maximum bending stress in the horizontal plane:

$$
\sigma_{H}=1.70 \mathrm{kN} / \mathrm{cm}^{2} \text {, }
$$

- the total stress:

$$
\sigma_{\max }=14.52 \mathrm{kN} / \mathrm{cm}^{2}<\sigma_{d}=23.67 \mathrm{kN} / \mathrm{cm}^{2} .
$$




\section{CONCLUSION}

In this research, a static analysis of the main girder of the double- beam bridge crane with two trolleys was performed to determine the critical position on the main girder, as well as the necessary static values to check the stiffness and strength conditions of the main girder. In addition to the analytical procedure, the verification of stiffness and strength conditions was performed numerically, using the SAP2000 software package.

The goal of the research is, first of all, to show that the mentioned software package can be applied to these types of supporting structures, and the necessary results can be obtained simply.

The process of forming a model of a bridge crane's girder in the SAP2000 software package is simple, using a line model, which makes this process fast. Using the Section Designer module, it can easily reach the desired cross-section and its geometric characteristics. In this way, the required geometric parameters of the main girder of the bridge crane in the initial design phase, conditions of deflection and strength of the girder, as well as all the necessary geometric characteristics used in the analysis are obtained very quickly and easily.

There is a strong agreement between the analytical results and the results from the SAP2000 software package (Chapter 2.5 and Chapter 2.6), which means that in the design process, designers can reliably rely on this software package when designing these types of carrying structures. It is noticed that in the vertical plane (whose loads are more dominant) the results from SAP2000 are slightly higher than those obtained analytically, which is on the side of caution, while those results for the horizontal plane are almost identical.

The previous chapter shows that for girders made of S355 material (which are most often used for these types of carrying structures) it is enough to check the deflections, which satisfies the conditions of strength and global stability of girder (bridge cranes with large spans, as in the observed example).

When determining the critical position on the main girder, it is noticed that the specific weight of the girder can be neglected, because the difference in values between expressions (17) and (46) is negligible, while the expression is much simpler (46). Also, it is noticed that the specific weight cannot be neglected when determining moments of bending and deflections.

The application of this model has shortcomings in terms of including the conditions of local stability of plates, as well as dynamic stiffness, but based on the obtained static quantities and geometric characteristics, they can be reached very quickly, especially if the recommendations for designing these types of structures are followed. Verification of these criteria would require the application of more complex models, which is the subject of further research.

\section{ACKNOWLEDGEMENTS}

This work has been supported by the Ministry of Education, Science and Technological Development of the Republic of Serbia, through the Contract for the scientificresearch activity realization and financing in 2021, 45103-9/2021-14/200108.

\section{REFERENCES}

[1] D. Zhang, W. Cheng and K. Cai, "Study on Prediction Deflection of at the Girder Midspan of Large Tonnage Gantry Crane Rigid legs", Applied Mechanics and Materials, Vol. 628, pp. 214-218, (2014)

[2] M. Delić, N. Pervan, M. Čolić and E. Mešić, "Theoretical and experimental analysis of the main girder double girder bridge crane", IJAAS, Vol. 6(4), pp. 75-80, (2019)

[3] S. Karakuş, "Optimum design of overhead crane girders under moving loads", Proceedings of 11 th International Conference on Vibration Problems "ICOVP-2013", Lisbon (Portugal), 9-12 September 2013, Article ID: 396, (2013)

[4] G. Pavlović, M. Savković, M. Gasić, R. Bulatović and N. Zdravković, "Optimization of the box section of the main girder of the double beam bridge crane according to the criteria of lateral stability and local stability of plates", Machine Design, Vol.4(4), pp. 197-204, (2012)

[5] A. Chakri, R. Khelif and M. Benouaret, "Optimization of the box-girder of overhead crane with constrained new bat algorithm", Rev. Sci. Technol., Vol. 35, pp. 187-203, (2017)

[6] A.M. Gohil, "Optimum Design of Bridge Girder of an EOT Crane Structure", Proceedings of 4th National Conference on Current Trends in Technology "NUCONE-2009", Ahmedabad (India), 25-27 November 2009, pp. 28-31, (2009)

[7] W. Meng, Z. Yang, X. Qi and J. Cai, "Reliability Analysis-Based Numerical Calculation of Metal Structure of Bridge Crane", Mathematical Problems in Engineering, Vol. 2013, Article ID: 260976, (2013)

[8] Z. Meng, T. Yifei and L. Xiangdong, "Finite element analysis of Bridge Crane Metal Structure Based on ABAQUS", MATEC Web of Conferences, Vol. 198, Article ID: 01004, (2018)

[9] P.F Liu, L.J. Xing, Y.L. Liu and J.Y. Zheng, "Strength Analysis and Optimal Design for Main Girder of Double-Trolley Overhead Traveling Crane Using Finite Element Method", J Fail. Anal. and Preven., Vol. 14, pp. 76-86, (2014)

[10] X. Wu, D. Zhang, J. Feng and J. Li, "Optimization and Realization of Bridge Girder Of 320-50t-22m Quenching Crane", Applied Mechanics and Materials, Vols. 84-85, pp. 363-367, (2011)

[11] G. Pavlović, M. Savković and N. Zdravković, "A comparative study of analytical and numerical analyses of the structure of the double-beam bridge crane with the rail in the middle of the main girder", Machine Design, Vol. 11(3), pp. 75-84, (2019)

[12] D. Ostrić and S. Tošić, "Cranes", Institute for Mechanization of the Faculty of Mechanical Engineering of the University in Belgrade, Belgrade (Serbia), (2005) 
[13] Z. Petković and D. Ostrić, "Metal Structures in Heavy Machinery I", Institute for Mechanization of the Faculty of Mechanical Engineering of the University in Belgrade, Belgrade (Yugoslavia), (1996)

[14] G. Pavlović, "Optimization of the Closed Cross Sections of the Main Main Girders of the Cranes by Using the Method of Lagrange Multipliers", PhD Thesis, University of Kragujevac, Faculty of Mechanical and Structural Engineering in Kraljevo (Serbia), (2013)

\section{Analiza glavnog nosača dvogredne mosne dizalice sa dva vitla}

Goran Pavlović ${ }^{*}$, Mile Savković ${ }^{2}$ Goran Marković Nebojša Zdravković ${ }^{2}$

${ }^{1}$ Faculty of Electronic Engineering, University of Niš, Niš (Serbia)

${ }^{2}$ Faculty of Mechanical and Civil Engineering in Kraljevo, University of Kragujevac, Kraljevo (Serbia)

U ovom istraživanju analiziran je problem izračunavanja potrebnih statičkih veličina glavnog nosača kutijastog poprečnog preseka dvogredne mosne dizalice sa dva vitla. Cilj je da se odredi kritični položaj na nosaču usled dejstva svih opterećenja u vertikalnoj ravni, $u$ funkciji ulaznih parametara, $i$ da se dobiju izrazi za izračunavanje ugiba u vertikalnoj $i$ horizontalnoj ravni, kao $i$ momenti savijanja $u$ ovim ravnima, odnosno maksimalni (ukupni) napon u nosaču. Provera rezultata izvršena je u programskom paketu SAP2000, pri čemu je pokazana prilično dobra korelacija između dobijenih rezultata, za predloženu metodu proračunskog modela kutijastog nosača, u pomenutom softverskom paketu. Cilj ovog istraživanja je prvenstveno da se pokaže kako se primenom programskog paketa SAP2000 na lak, brz $i$ jednostavan način može izvršiti dimenzionisanje $i$ projektovanje ove vrste noseće strukture, uzimajući u obzir važne statičke uslove koji moraju biti zadovoljeni. Primenom predložene metode modelovanja i korišćenjem određenog modula u pomenutom softverskom paketu, projektant lako dolazi do preliminarnih geometrijskih vrednosti nosača u početnoj fazi projektovanja, pri čemu se $u$ potpunosti može osloniti na dobijene rezultate. Takođe, dobijaju se sve geometrijske veličine potrebne za naredne faze projektovanja i proračuna. Date su smernice o tome kako u ovom softverskom paketu pripremiti proračunski model za ove vrste nosivih struktura, kao $i$ preporuke $u$ vezi sa projektovanjem ovih vrsta nosivih struktura izradenih od materijala S355.

Ključne reči: Mosna dizalica, Naponska stanja, Ugibi, SAP2000 